\title{
The Impact of Russia's Oil-Dominated Energy Economic Changes on the Exchange Rate of Russian Ruble - Chinese Renminbi
}

\author{
Maoguo Wu (PhD) \\ Yue Yu (Master Candidate) \\ SHU-UTS SILC Business School, Shanghai University, China
}

doi: 10.19044/esj.2017.v13n22p173 URL:http://dx.doi.org/10.19044/esj.2017.v13n22p173

\begin{abstract}
Russia's economic development has a close relation with China, due to geographical and historical reasons. This paper investigates whether the ruble - renminbi exchange rate changes accordingly when the pillar industry of Russia is drastically changing, and how the exchange rate changes and how it affects Russia's economic development. In this paper, data of 7 variables spanning 122 months are selected based on related literature and availability of data. Regression analysis and empirical tests are carried out consequently. The results show that the energy price index represented by oil prices is negatively correlated with the exchange rate, and the explanatory power is as high as $41.1 \%$. Following basic arbitrage methods and strategies, this paper verifies the feasibility of using arbitrage by comparing actual exchange rates with forecasted exchange rates. According to empirical results, problems witnessed in the process of ruble internationalization provides policy implications for China. China's economy is utilized as an example to discuss the shortcomings of Russia's economy. Related solutions are proposed.
\end{abstract}

Keywords: Russian Ruble, Chinese Renminbi, Exchange Rate, Energy Price Index, Arbitrage

\section{Introduction}

Russia's economic development is heavily dependent on the export of oil and gas. More than half of Russia's budget and foreign exchange earnings come from its oil and gas resources. Russia's economic development depends on the degree of dependence on resources, which can also be revealed by the serious imbalance of Russia's economic structure. In addition, Russian government takes Brent oil prices, the core of the 
international commodity price system, as an important reference target when formulating fiscal policy, monetary policy, budget, and annual economic development plan. For example, Russia's 2014 budget is based on Brent oil price of $\$ 93$ per barrel according to the government's initial plan. According to the economic data released by Bloomberg News, the Brent oil prices fell by $48 \%$ in 2014 , while the Russian ruble depreciated by $45 \%$ against the US dollar, which could reveal a high correlation between the depreciation of the ruble and the fall in oil prices. The continuous slump in international oil prices in 2014 is undoubtedly the most direct and serious impact on Russia's economic growth, contributing to more than one-third of its fiscal and foreign exchange earnings. In addition, during the year of 2014, the exchange rate of Russian ruble against USD dollar depreciated by more than a half, seriously disrupting the normal operation of Russia's economy. To this end, on November $10^{\text {th }} 2014$, the Russian monetary authority issued a document announcing the implementation of a free floating exchange rate system, an initiative to give up the long-standing fixed exchange rate system. The most direct impact of the oil turmoil on the international money market in 2014 was the sharp change in the ruble exchange rate. Although changes in the exchange rate are caused by a variety of factors, it is undeniable that the oil-based energy market price changes, caused by changes in the ruble exchange rate, is one of the main factors. This paper focuses on the impact of energy price changes on the value of Russian ruble against Chinese renminbi.

China and Russia are very important strategic partnership countries. The two countries not only have a high degree of cooperation in political field and military field, but also have a deep economic exchange basis. The ruble is currently a relatively active currency in the Chinese foreign exchange market, and factors influencing the value of ruble can effectively guide the investment behavior of people and enterprises in China. For foreign trade enterprises and financial institutions in Russia, it can help enterprises to effectively avoid foreign exchange risk. It also helps enterprises in the foreign exchange market access to non-operating income through effective forecasting, increasing the cash flow to improve the core competitiveness of enterprises. For investors, the foreign exchange market is ever changing, and any factor that affects exchange rate changes has an impact on their investment behavior. In order to further clarify the direct link between investment and exchange rate changes and how the real economic changes affect the exchange rate, this paper attempts to answer the abovementioned questions by empirically testing the impact of international energy price on ruble - renminbi exchange rate. By analyzing a large amount of data, this paper draws the conclusion that the pillar industry has a major impact on the value of the national sovereign currency. Lessons learned from Russian can 
help keep the RMB exchange rate stable and develop the theory of RMB internationalization.

For the Chinese government, a series of challenges, such as the relation between the RMB exchange rate and China's real economic development, how to maintain the RMB exchange rate in a favorable direction, how to effectively make the RMB a current money beyond East Asia and become an international currency etc.. It is effective to learn from the experience of Russia.

The remaining part of this paper is as follows. Section 2 reviews related literature. Section 3 analyzes the economic status of Russia, its economic structure, the status of oil in Russia, and reasons for the drastic changes in the ruble exchange rate in 2014. A brief analysis of the status of ruble in the foreign exchange market is also discussed. Section 4 is devoted to empirical analysis. Section 5 proposes policy implications. Section 6 concludes the paper.

\section{Related Literature}

Chen (2014) points out that United States has a growth of 1.5 million barrels instead of reducing 2.7 million barrels in a single week. In this context, US, a big oil consumption country, and Russia, a major producer of oil, witnessed the exchange rate plunged $50 \%$. It also triggered a series of chain reaction, including the RTS stock market falling by $17 \%$, economic loss of up to 100 billion US dollars, coupled with Russian analysts' estimation of a loss of 40 billion due to Western sanctions. In all, Russia lost a huge amount, roughly 140 billion US dollars.

Wang (1993) summarizes six major reasons for the collapse of the ruble exchange rate through case analysis. It argues that domestic production decline, severe inflation (compared with December 1991, consumer prices of consumer goods and services in Russia rose by 25 times in 1992), international income reduction, most of the Western aid program has not been honored, and the prevalence of buying US dollar, all contribute to the artificial underestimation of the value of ruble. At the same time, the paper argues that the stability of a country's currency depends fundamentally on the effective growth of the country's production, increase in its export capacity, and its production efficiency.

Xie (2015) investigates the devaluation of the ruble in 2014. International oil prices volatility and the Fed's implementation of Quantitative Easing seriously affect emerging economies. The ruble itself implies huge currency deficiencies. Ukrainian geopolitical and international sanctions and the imbalance in Russia's economic structure are the main reasons leading to the devaluation of the ruble. At the same time, the paper 
also analyzes the impact of the devaluation of the ruble. First of all, the Federal Reserve withdrew from the quantitative easing policy and international oil prices plummeted. The Federal Reserve originally prepared to invest in Russia's large international oil investment funds, but it also withdrew from the Russian domestic capital market. This is a serious blow to the Russian oil exports, which is heavily dependent on crude oil. Second, due to international sanctions, Russian enterprises' financing and introduction of technical equipment are blocked in the international market, which led to Russian business giants cutting production, rising unemployment, and sustained high inflation. Russia's economy entered a stage of stagnation.

Cao (2014) points out that Russian people are not optimistic about the exchange rate of ruble based on analysis of the relation between Russian people's daily necessities and the exchange rate of ruble. For example, at the beginning of 2014, the ruble depreciated by about $7 \%$ against the dollar, while the price of alcohol in Russian market rose by about $10 \%$. The price of daily food, such as that of onions and potatoes, rose by $7 \%$ and $10 \%$, respectively.

$\mathrm{Xu}$ (2014) finds that although Russia's foreign exchange system is relatively backward, its living standard is gradually getting close to that of the West, which makes the application of DD-AA model become a reality. It also provides an important supporting point, i.e., the main direction of the ruble in the international market is "ruble - dollar trading", although the proportion of the transaction gradually declines, but still plays an important role in international exchange market.

Sossounov and Ushakov (2009) argues that factors such as money supply are the influencing elements of the exchange rate of the ruble, but also points out that there are also autocorrelation among factors that affect exchange rate changes. For example, interest rate changes not only affect exchange rates but also affect the money supply.

\section{Russia's Economy and Foreign Exchange Market 3.1 Russia's Economic Situation}

2014 is a very difficult year for Russia. Russia's GDP increased by only $0.6 \%$ compared with last year. Affected by a series of events in 2014, Russia's economy gradually showed signals of stagnation. Russia's GDP is expected to show negative growth in the next two years. Russia's central bank issued a substantial rate hike of 650 basis points in December 14 in order to stabilize the economic situation, and to maintain a relatively modest change in its sovereign currency.

Russia's economy was largely affected by the sharp fall in international crude oil prices, economic sanctions from Western countries, and the 
devaluation of its sovereign currency, namely rubles. Change of the ruble exchange rate is the dependent variable, and change of the oil price is the main explanatory variable.

Although the world economy has generally embarked on the road to economic recovery after the economic crisis, the sequelae of the weak economy still exists. Growth of the world's crude oil market demand is almost stalled, while the pattern of crude oil supply has changed. The world oil market changed from the "Russia-OPEC" duopoly into a market dominated by three countries since US joined in. Due to progress in petroleum technology, it is getting easy to exploit shale oil. Shale oil is also the largest oil reserve in US. Therefore, the crude oil market has experienced a substantial increase in production. At this time, US intended to promote economic growth through the new crude oil economy due to its substantial increase in production. Russia's economic development is mainly dependent on oil, so it is difficult to cut production. The world oil market generally relies on OPEC in the hope that it can negotiate a cut in oil production to maintain oil prices. Nevertheless, OPEC refused to cut production. Instead, it maintained its output at a relatively high level after several rounds of negotiations. Coupled with the generally low world's expectations of crude oil, the end result was the 2014 world oil production oversupply, and crude oil prices plummeting.

In 2014, Putin made a decision to seize the Crimea through paramilitary operations. As the Russian military power and the Braille nationalism support the Crimean nationalism, this decision makes the Crimea part of the Russian territory. The rapid development of the situation makes the European society generally panic. US is also concerned about this situation. To this end, Western countries have to use economic sanctions to protest against Russia. Due to Russia's special economic structure, Western countries' economic sanctions have produced obvious results. At the same time, other currencies against the ruble substantially appreciated. Many people went to Russia for shopping of luxury goods, and even forced some of Russia's international merchandise to sell out. Some luxury brands have to increase prices constantly. Russian people began to sell rubles in a frenzy, making the ruble exchange rate go down all the way. The stability of the exchange rate of ruble is seriously threatened. Russia's central bank had to sell more than 60 billion US dollars to stabilize the exchange rate. Ruble was suffering an extremely harsh Siberian winter.

\subsection{Russia's Economic Structure}

According to the Russian National Bureau of Statistics, Table 1 shows Russia's balance of payments in 2014. 
Table 1 Russia's Balance of Payments in 2014 Unit: \$100 Million

\begin{tabular}{ll|ll}
\hline \hline Current Account & 712.8 & Financial Account & 556.9 \\
\hline \hline Credit of Goods & 5274 & Assets of Directive Investments & 488 \\
Debit of Goods & 3357 & Liabilities of Directive Investments & 505 \\
Credit of Service & 623.4 & Assets of Portfolio Investments & 22 \\
Debit of Service & 1089 & Liabilities of Portfolio Investments & 193 \\
Credit of Income & 477.6 & Assets of Other Investments & 167 \\
Debit of Income & 54 & Liabilities of Other Investments & 180 \\
\hline \hline
\end{tabular}

Source: Russian National Bureau of Statistics

As can be seen from Table 1, Russia's current account is $\$ 71.28$ billion, its capital account is $\$ 52.2$ billion, and the financial account is $\$ 55.69$ billion. This shows that Russia, as a trade surplus country, is a net exporter in the world, with debit of goods up to $\$ 335.77$ billion, more than the sum of all other projects. Its main surplus is concentrated on commodity trade.

In 2013, Russia's GDP constituted of $\$ 143.7$ billion in mineral, $\$ 175$ billion in manufacturing and $\$ 150$ billion in real estate and commercial activity, which are the three pillar industries of Russia's economy. Minerals represent Russia's oil and gas exploration, and the manufacturing industry represents heavy industry based on arms production. Real estate and business are not considered in this paper. Therefore, the industrial structure of Russia is as follows. Industrial structure is largely dominated by the oil industry. Industrial development is not balanced. The industry has serious emphasis. Resource industry and military industry/heavy manufacturing industry are the two major industries. The resource industry includes energy and real estate.

In general, the three pillar industries of Russia's economy are: resource industry, heavy manufacturing industry, and real estate. The foreign exchange market is closely related with the resource industry and heavy manufacturing industry. Therefore, this paper studies the two industries and their impact on the value of ruble.

\subsection{The Position of Ruble in the Foreign Exchange Market}

It is generally believed that the foreign exchange market has four common currencies, US Dollar, Euro, Pound Sterling, and Japanese Yen. With the rising status of renminbi, in the near future, renminbi is likely to become an international currency. The influence of RMB is gradually expanding. It is gradually replacing the yen as the mainstream Asian currency in circulation. Meanwhile, ruble has little influence in the world. For China and some former CIS countries and other European energy importing countries, due to frequent bilateral trade, the ruble still has certain 
influence. In order to study the value of ruble in a relatively objective way, and to collect exchange rate data effectively, renminbi is used to evaluate the value of rubles.

As far as the foreign exchange market is concerned, the Russian government has made a great deal of effort to seek a rise in its monetary status. Although Russia's economy itself has a certain degree of closeness, but the ruble has been in the process of internationalization. Once this process is realized, ruble will become a free floating currency, and the process is irreversible. Stability of the value of ruble is also the stability of the exchange rate. The stabilization tool of ruble exchange rate is to seek international trade and oil. In terms of trade, in addition to China, other CIS countries are Russia's main trading partners. However, the scale of the trade is very limited. Trade alone cannot support the stability of the exchange rate. European countries which import oil from Russia resort to importing from the Middle East after economic sanctions against Russia started, leading to a worse situation for the Russian energy industry. Russia's oil economy is facing a huge plight of price plummeting. Thus, the sharp decline in the ruble exchange rate was inevitable. Russian Duma had to make decisions such as selling dollars, raising interest rates and other ways in order to stabilize the exchange rate, which only has a temporary effect. To restore the status of ruble before it collapses, Russia has to reform its economic structure.

\section{Empirical Analysis}

\subsection{The Data}

This paper uses 7 variables spanning 122 months. 7 explanatory variables are the international market energy price index (INDEX), net exports (NETEX), weighted annual interest rates (RATE), money supply (MS), ruble exchange rate (EXRATE), price level (CPI) and gross domestic product (GDP). 122 months refer to January 2005 to February 2015. INDEX, NETEX, RATE, MS, CPI, GDP are explanatory variables, and EXRATE is the explained variable. All data are gathered from the Russian central bank and Russian National Bureau of Statistics.

There are three reasons why international energy price index is chosen over international crude oil prices. First, data on international crude oil prices are not fully disclosed. Second, in recent years, especially in 2014, the proportion of Russian natural gas in its energy industry is gradually rising. The energy price index includes this subtle change. Third, energy price index move along with international crude oil prices in the same trend, which can be found in the recent trend of energy prices.

There are three reasons why this paper uses net exports instead of heavy manufacturing industry represented by the military industry. First, data on 
military export is not published. Second, this paper studies the exchange rate of ruble, while heavy industry has little effect on exchange rates. Third, for Russia, the main competitiveness of its exports lies in heavy industry, while other exports are relatively less important. Using data on net exports not only excludes heavy industry exports, but also eliminates the effects of import and export of other industries.

From the DD-AA model, the annual interest rate and the money supply are also effective financial factors that affect the exchange rate changes. When studying the impact of oil price on the exchange rate of ruble, it is imperative to hold other influencing factors fixed and therefore add in as many explanatory variables as possible. DD-AA model depicts that interest rate and money supply are two influencing factors of exchange rate. At the same time, in the basic assumptions of DD-AA, M/P should remain relatively stable, so this paper adds price level, proxied by CPI, as an explanatory variable. In addition, GDP is added in regression as an explanatory variable, as GDP reveals a country's overall economy.

There is an important reason for choosing these 122 months as used in the paper. 2005 to 2015 is a special historical period of Russia's rapid economic development, In particular, 2014 was not only a year of drastic changes for oil prices, but also a year of intense turmoil for Russian ruble. These two changes continue to affect Russia's economy until the beginning of 2015. These 122 months is deemed an ideal time period to investigate the relation between the ruble exchange rate and the oil price.

Descriptive statistics of all variables are summarized in Table 2.

Table 2 Descriptive Statistics of Variables

\begin{tabular}{llllll}
\hline \hline Variables & Observation & Mean & Standard Deviation & Min & Max \\
\hline \hline EXRATE & 122 & 30.4891 & 3.899786 & 26.09839 & 56.26 \\
INDEX & 122 & 113.4017 & 22.75542 & 63 & 161.2 \\
RATE & 122 & 5.233871 & 1.104151 & 4.007916 & 9.44 \\
MS & 122 & 7764.472 & 400.2103 & 7006.876 & 8383.6 \\
NETEX & 122 & 7.523819 & 1.839859 & 4.3 & 11.99 \\
GDP & 122 & 116.9365 & 41.69374 & 47.6 & 190 \\
CPI & 122 & 309.0844 & 77.35452 & 182 & 488.3 \\
\hline \hline
\end{tabular}

As can be seen from Table 2, EXRATE and the key explanatory variable INDEX have a mean of 30.4891 and 113.4017 , respectively. The minimum of EXRATE is 26.09839, and the maximum value is 56.26, indicating that rubles experienced a very volatile period. The minimum value of INDEX is 63, and the maximum value is 161.2, which shows that international market energy prices have substantial changes. 


\subsection{Econometric Analysis \\ 4.2.1 Stationarity Test}

The unit root test method used in this paper is the Augmented DickeyFuller (ADF) test. The $t$ statistic value of the stationarity test is shown in Table 3. The $t$ statistic of ADF test of the LEXRATE time series is not significant at the $10 \%$ confidence level and therefore not able to reject the original hypothesis that the time series LEXRATE has unit root, i.e., the LEXRATE time series is not stationary. Take the first-order difference of LEXRATE and conduct the ADF unit root test again, DLEXRATE is found to be stationary at the $1 \%$ confidence level. Similarly, DLINDEX, DLGDP and DCPI are all first-order stationary. From Table 3, it can be found that LNETEX, RATE and LMS are all stationary.

Table 3 Stationarity Test of Variables

\begin{tabular}{|c|c|c|c|c|c|}
\hline Variables & $\mathrm{ADF}$ & $\begin{array}{l}1 \% \\
\text { Value }\end{array}$ & $\begin{array}{r}\text { Critical 5\% } \\
\text { Value }\end{array}$ & $\begin{array}{r}\text { Critical } 10 \% \\
\text { Value }\end{array}$ & Critical Conclusion \\
\hline EXRATE & 4.578 & -3.503 & -2.889 & -2.579 & Non-Stationary \\
\hline LEXRATE & 2.222 & -3.503 & -2.889 & -2.579 & Non-Stationary \\
\hline DLEXRATE & $-13.06 * * *$ & -3.503 & -2.889 & -2.579 & Stationary \\
\hline INDEX & -1.070 & -3.503 & -2.889 & -2.579 & Non-Stationary \\
\hline LINDEX & -0.739 & -3.503 & -2.889 & -2.579 & Non-Stationary \\
\hline DLINDEX & $-5.921 * * *$ & -3.503 & -2.889 & -2.579 & Stationary \\
\hline NETEX & $-6.445 * * *$ & -3.503 & -2.889 & -2.579 & Stationary \\
\hline LNETEX & $-6.556 * * *$ & -3.503 & -2.889 & -2.579 & Stationary \\
\hline RATE & $-3.795 * * *$ & -3.503 & -2.889 & -2.579 & Stationary \\
\hline MS & $-5.223 * * *$ & -3.503 & -2.889 & -2.579 & Stationary \\
\hline LMS & $-5.299 * * *$ & -3.503 & -2.889 & -2.579 & Stationary \\
\hline GDP & -1.454 & -3.503 & -2.889 & -2.579 & Non-Stationary \\
\hline LGDP & -1.876 & -3.503 & -2.889 & -2.579 & Non-Stationary \\
\hline DLGDP & $-11.16^{* * *}$ & -3.503 & -2.889 & -2.579 & Stationary \\
\hline CPI & 3.019 & -3.503 & -2.889 & -2.579 & Non-Stationary \\
\hline DCPI & $-8.542 * * *$ & -3.503 & -2.889 & -2.579 & Stationary \\
\hline
\end{tabular}

Note: LEXRATE, LINDEX, LNETEX, LMS and LGDP are natural logarithm of original variables. DLEXRATE, DLINDEX and DLGDP are first-order differentials of original variables. $* * *, * *$ and $*$ represent $1 \%, 5 \%$ and $10 \%$ significance levels, respectively.

\subsubsection{Granger Causality Test}

Before determining whether there is a Granger causality among variables, OLS is first established. Then the significance level of the lagged explanatory variables is checked on the basis of the OLS model. Before building the OLS model, this paper first determines the lag. Adding too many lagged items increase the forecast error, and adding too few lagged items exclude relevant information. There are three methods that can be used 
to detect the optimal number of lag periods, SBIC, AIC, and HQIC. The results obtained by the three methods are not consistent. Since this paper uses Vector Auto Regression (VAR), AIC is the most suitable algorithm for VAR, results obtained in this paper reply on AIC has the selection method. Two lags are selected as the optimal lag. Granger causality test is performed to check the relation among the explained variable (EXRATE) and explanatory variables (INDEX, RATE, MS, NETEX, GDP, and CPI). The results are shown in Table 4.

Table 4 Granger Causality Test Based on OLS

\begin{tabular}{|c|c|c|c|c|c|}
\hline Variables & $\begin{array}{l}\text { Number of } \\
\text { Periods }\end{array}$ & $\begin{array}{c}\text { Lag Coefficient } \\
\text { Value }\end{array}$ & Standard Err & T-Value & $\mathrm{P}>|\mathrm{t}|$ \\
\hline \multirow{2}{*}{ DLEXRATE } & L1 & -0.3510796 & -0.0987377 & -3.56 & 0.001 \\
\hline & L2 & 0.1462459 & -0.0976486 & 1.5 & 0.137 \\
\hline \multirow{2}{*}{ DLINDEX } & L1 & -0.0382944 & -0.0589207 & -0.65 & 0.017 \\
\hline & L2 & -0.0052108 & -0.0608946 & -0.09 & 0.932 \\
\hline \multirow{2}{*}{ LNETEX } & L1 & 0.0103073 & 0.0177353 & 0.58 & 0.032 \\
\hline & L2 & 0.0156231 & -0.0181449 & 0.86 & 0.391 \\
\hline \multirow{2}{*}{ RATE } & L1 & 0.0095288 & -0.0045095 & 2.11 & 0.037 \\
\hline & L2 & 0.0029932 & -0.0049156 & 0.61 & 0.544 \\
\hline \multirow{2}{*}{ LMS } & L1 & -0.0187056 & 0.088195 & -0.21 & 0.032 \\
\hline & L2 & -0.1007874 & -0.086349 & -1.17 & 0.246 \\
\hline \multirow{2}{*}{ DLGDP } & L1 & -0.0876365 & -0.0710323 & -1.23 & 0.02 \\
\hline & L2 & -0.008919 & -0.0718416 & -0.12 & 0.901 \\
\hline \multirow{2}{*}{ DCPI } & L1 & 0.002121 & -0.0012212 & 1.74 & 0.015 \\
\hline & L2 & 0.0014022 & -0.0012628 & 1.11 & 0.269 \\
\hline
\end{tabular}

Table 4 shows that the p-values of INDEX, RATE, MS, NETEX, GDP and CPI in the first lagged period are very small, and all are less than 5\% of the significance level. So there are causal relations between the six variables and the ruble exchange rate. That is, explanatory variables cause changes in the explained variable. INDEX, RATE, MS, NETEX, GDP and CPI change are the Granger causes of EXRATE. The p-value of these six variables in lag two are greater than 0.1 , so do not reject its null hypothesis. That is to say, these six variables are not the Granger causes of exchange rate changes. In addition, it can be seen from Table 4 that the ruble exchange rate has a pvalue of 0.001 , much less than $1 \%$ of the significance level. Therefore, reject the null hypothesis. That is to say, the lagged ruble exchange rate also has a significant impact on the current ruble exchange rate changes. 


\subsubsection{Preliminary Tests}

This paper utilizes Breusch-Godfrey method and Durbin-Watson method to test serial correlation. Both test results show that the regression has serial correlation. Therefore, Cochrane-Orcutt AR (1) regression is conducted to eliminate serial correlation. Six regressions are run by adding explanatory variables one by one. The regression results are summarized in Table 5.

As can be seen from Table 5, no matter how many variables are added to the regression, INDEX always affects EXRATE even at the 1\% significance level. Besides, at the $10 \%$ significance level, all explanatory variables are related to the explanatory variables, regardless of the number of regressions. Moreover, in the case of adding all explanatory variables to the regression, are explanatory variables are found to be significant at 5\% significance level.

Table 5 Regression Results and Robustness Check

\begin{tabular}{|c|c|c|c|c|c|c|}
\hline \multirow{3}{*}{ Variables } & \multicolumn{6}{|l|}{ DLEXRATE } \\
\hline & Regression 1 & Regression 2 & Regression 3 & Regression 4 & Regression 5 & Regression 6 \\
\hline & $\begin{array}{l}\text { Coefficient } \\
\text { (std.) }\end{array}$ & $\begin{array}{l}\text { Coefficient } \\
\text { (std.) }\end{array}$ & $\begin{array}{l}\text { Coefficient } \\
\text { (std.) }\end{array}$ & $\begin{array}{l}\text { Coefficient } \\
\text { (std.) }\end{array}$ & $\begin{array}{l}\text { Coefficient } \\
\text { (std.) }\end{array}$ & $\begin{array}{l}\text { Coefficient } \\
\text { (std.) }\end{array}$ \\
\hline DLINDEX & $\begin{array}{l}-.1427604 * \\
(.046124)\end{array}$ & $\begin{array}{l}-.058967 * \\
(.043691)\end{array}$ & $\begin{array}{l}-.0433544 * * \\
(.0422884)\end{array}$ & $\begin{array}{l}.044614 * * \\
(.04245)\end{array}$ & $\begin{array}{l}-.0379761 * * \\
(.0428072)\end{array}$ & $\begin{array}{l}-.0334052 * * \\
(.0426295)\end{array}$ \\
\hline L1.RATE & & $\begin{array}{l}.0129655^{* * * *} \\
(.002587) \\
\end{array}$ & $\begin{array}{l}.0091632 * * \\
(.0027822) \\
\end{array}$ & $\begin{array}{l}.0092892^{* *} \\
(.00289)\end{array}$ & $\begin{array}{l}.00952 * \\
(.0028) \\
\end{array}$ & $\begin{array}{l}.010066^{*} \\
(.0028037) \\
\end{array}$ \\
\hline L1.DCPI & & & $\begin{array}{l}.0031475 * * * \\
(.0010249)\end{array}$ & $\begin{array}{l}.0030876 * * * \\
(.0010342)\end{array}$ & $\begin{array}{l}.0029343 * * \\
(.0010421)\end{array}$ & $\begin{array}{l}.0024293 * * \\
(.0010843)\end{array}$ \\
\hline LNETEX & & & & $\begin{array}{l}.0055517 * * \\
(.0109643)\end{array}$ & $\begin{array}{l}.0160179 * * \\
(.0148827)\end{array}$ & $\begin{array}{l}.0117427 * * \\
(.0150363)\end{array}$ \\
\hline LMS & & & & & $\begin{array}{l}-.0668631 * * \\
(.0646491) \\
\end{array}$ & $\begin{array}{l}-.0623549 * * \\
(.0642956) \\
\end{array}$ \\
\hline DLGDP & & & & & & $\begin{array}{l}-.1009045^{*} \\
(.0643784)\end{array}$ \\
\hline
\end{tabular}

Note: $*, * *, * * *$ represent significance at 10\%, 5\%, and 1\% significance level, respectively.

\subsubsection{CHOW Test and VAR Test}

The ruble exchange rate fell sharply in February 2014, and the dummy variable (BREAK) is defined according to the singular value of the data. The variable BREAK is set 0 before February 2014, and it is set 1 after February 2014. Interaction terms, created by multiplying all explanatory variables with BREAK, are augmented to Cochrane-Orcutt AR (1) regression. The regression equation is (1). 
$D L E X R A T E=\beta_{0}+\beta_{1} D L I N D E X+\beta_{2} R A T E(-1)+\beta_{3} D C P I+\beta_{4} \operatorname{LNETEX}(-1)$

$+\beta_{5} L M S(-1)+\beta_{6} D L G D P+\beta_{7} B R E A K+\beta_{8} B R E A K^{*} D L I N D E X+$

$\beta_{9} B R E A K * R A T E(-1)+\beta_{10} B R E A K * D C P I+\beta_{11} B R E A K * \operatorname{LNETEX}(-1)$

$+\beta_{12} B R E A K^{*} L M S(-1)+\beta_{13} B R E A K^{*} D L G D P$,

(1)

A joint significance test is performed. The p-value of 0.0018 is less than 0.05 , so reject the null hypothesis. This indicates that BREAK is significant, i.e., there is a structure break of the ruble exchange rate around February 2014. The structure break is likely to be related to the collapse of oil prices and Western economic sanctions.

In addition, due to the uncertainty of the variable endogeneity, this paper conducts VAR test of each variable. The test results are in Table 6.

It can be seen from Table 6 that each explanatory variable is Granger causing the explained variable in different lag periods. For example, DLINDEX's p-value of L1 is 0.048, then reject the null hypothesis, i.e., at the $5 \%$ significance level there is two-way causality between the two. Similarly, it can be concluded that LNETEX, RATE, LMS, DLGDP and DCPI have a 5\% significance level with the explained variable in lag two.

Table 6 Granger Causality Test Based on VAR

\begin{tabular}{|c|c|c|c|c|c|}
\hline Variables & Number of lag periods & Coefficient value & Standard deviation & $\mathrm{z}$ value & $\mathrm{P}>|\mathrm{z}|$ \\
\hline \multirow{2}{*}{ DLINDEX } & L1 & -0.0365061 & 0.0621538 & -0.59 & 0.048 \\
\hline & L2 & -0.0282368 & 0.0616885 & -0.46 & 0.065 \\
\hline \multirow{2}{*}{ LNETEX } & $\mathrm{L} 2$ & 0.0334664 & 0.0180988 & 1.85 & 0.024 \\
\hline & L3 & -0.0261963 & 0.0186652 & -1.40 & 0.016 \\
\hline \multirow{2}{*}{ RATE } & L2 & 0.0053057 & 0.0047291 & 1.12 & 0.026 \\
\hline & L3 & 0.0114976 & 0.0052271 & 2.20 & 0.028 \\
\hline \multirow{2}{*}{ LMS } & $\mathrm{L} 2$ & -0.1111 & 0.0899618 & -1.23 & 0.021 \\
\hline & L3 & 0.0641023 & 0.0872604 & 0.73 & 0.046 \\
\hline \multirow{2}{*}{ DLGDP } & L2 & -0.0164892 & 0.0741668 & -0.22 & 0.012 \\
\hline & L3 & -0.0759267 & 0.0728897 & -1.04 & 0.029 \\
\hline \multirow{2}{*}{ DCPI } & L2 & 0.0016377 & 0.0012895 & 1.27 & 0.020 \\
\hline & L3 & 0.0003706 & 0.0012921 & 0.29 & 0.074 \\
\hline
\end{tabular}

Table 7 provides further tests on causality. The results are as follows:

Table 7 Granger Causality Test - Variable Selection

\begin{tabular}{lllll}
\hline \hline Equation & Excluded & chi2 & df & Prob > chi2 \\
\hline \hline DLEXRATE & DLINDEX & 0.6249 & 2 & 0.0032 \\
DLEXRATE & LNETEX & 1.3883 & 2 & 0.0499 \\
DLEXRATE & RATE & 10.302 & 2 & 0.006 \\
DLEXRATE & LMS & 2.0517 & 2 & 0.0358 \\
DLEXRATE & DLGDP & 1.7417 & 2 & 0.0419 \\
DLEXRATE & DCPI & 4.8966 & 2 & 0.036 \\
\hline \hline
\end{tabular}


It can be seen from Table 7 that the $\mathrm{P}$ values of DLINDEX, LNETEX, RATE, LMS, DLGDP and DCPI are 0.0032, 0.0499, 0.006, 0.0358, 0.0419 and 0.036 , respectively. That is, all explanatory variables affect the explained variables to varying degrees at the $5 \%$ significance level.

\subsubsection{Impulse Response}

Based on the above VAR model, impulse response function can be used to analyze the response of the ruble exchange rate to the impulse from the international energy price index, net export and weighted annual interest rate. Figure 1 shows the results.
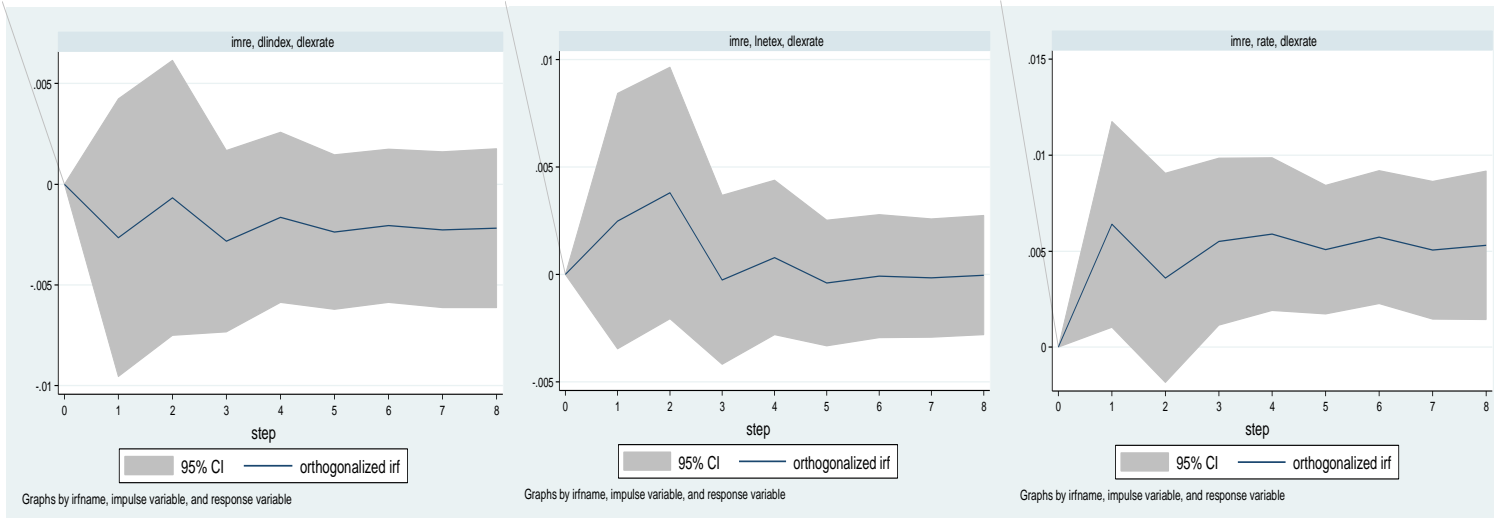

Figure 1 DLINDEX, LNETEX and RATE's Impulse Response to DLEXRATE

As can be seen from Figure 1, the ruble exchange rate does not respond immediately to impulse from the international energy price index. In the first period, the response of DLEXRATE to DLINDEX is maximized and negative. After that, response of DLEXRATE slowly attenuates and stabilizes. It remain negatively correlated. This shows that the international energy price index has a long-term negative impact on the ruble exchange rate. When the international energy price index rises, the ruble exchange rate appreciates.

Figure 1 also shows the impulse response of the ruble exchange rate to net exports. The ruble exchange rate DLEXRATE does not respond immediately to the impulse from net exports LNETEX. In the second period, response of DLEXRATE to the impulse of net export LNETEX reaches the maximum and it is positive. After that, the response of DLEXRATE attenuates until the fifth period and eventually reaches zero. Likewise, DLEXRATE does not respond to RATE at period 0. It reaches the maximum in the first period and it is positive. Afterwards it begins to stabilize from the third period, and maintains a positive relation. 


\subsubsection{Variance Decomposition}

Variance decomposition is used to analyze the contribution rate of INDEX, RATE, MS, NETEX, GDP, and CPI to the ruble exchange rate. Table 8 shows the results.

Table 8 Variance Decomposition

\begin{tabular}{lllllll}
\hline \hline $\mathrm{Gr}$ & Variables & Factor & Standard Deviation & $\mathrm{P}>|\mathrm{t}|$ & Std. Coef. & Shapley \% $\mathrm{R}^{2}$ \\
\hline \hline 1 & DLINDEX & -.0273838 & .0407708 & 0.050 & -0.0446 & 41.0616 \\
2 & L.LNETEX & .0072953 & .0187947 & 0.060 & 0.0419 & 10.5736 \\
3 & L.RATE & $.0098218 * *$ & .0037569 & 0.001 & 0.013 & 26.6961 \\
4 & L.LMS & -.0548943 & .0794552 & 0.052 & -0.0702 & 2.1735 \\
5 & L.DLGDP & $-.1076196 *$ & .0573505 & 0.012 & -0.0257 & 12.0375 \\
6 & L.DCPI & $.0027368 * *$ & .0012998 & 0.004 & 0.0207 & 7.25 \\
\hline
\end{tabular}

It can be seen in Table 8 that $41.1 \%$ of the ruble exchange rate fluctuation is due to changes in international energy price index. This reflects the importance of oil and gas in the economic development of Russia. For example, in the second half of 2008 and the second half of 2014, while the world crude oil market experienced downturn, the ruble exchange rate had significant fluctuations. This also reveals that the decline in crude oil export prices directly affects Russian foreign exchange earnings and foreign exchange reserves, thus affecting the stability of the ruble exchange rate. In addition, the contribution rate of RATE is $26.7 \%$, and the contribution rate of GDP is $12.0 \%$. NETEX and CPI contributes $10.6 \%$ and $7.3 \%$ to the changes of DLINDEX, respectively. Dependence of the ruble exchange rate on the international energy price index is evident.

\subsection{Arbitrage}

Arbitrage usually refers to differences in exchange rates in different foreign exchange markets at the same time. So buy in the low exchange rate market, and sell in the high exchange rate market to earn the difference. Equation (1) to a certain degree can make prediction of the ruble exchange rate over a limited period of time. Based on this prediction, this paper proposes two kinds of arbitrage schemes.

First of all, price difference caused by fluctuation is the base of all arbitrage. If the foreign exchange market has been stable and no change is speculated, then arbitrage cannot take place. If frequent fluctuation is observed, then two arbitrage opportunities emerge. The first one is that the future ruble exchange rate is predicted to be greater than the current exchange rate. The second one is that the future ruble exchange rate is predicted to be less than the current ruble exchange rate changes.

For the first scenario, the scheme is to borrow rubles in the foreign exchange market. Afterwards, convert the borrowed currency, say dollars, 
into rubles. Then divide rubles into two parts until the loan contract period expires. Part of the ruble is to be converted into dollar, as the same amount of ruble would need less dollars should ruble appreciate. The leftover is the profit of the arbitrage.

For the second scenario, the scheme is to sell rubles in the foreign exchange market. If rubles depreciate as expected, then buy back rubles. Because at this time the exchange rate becomes lower, then the same amount of rubles can be bought with less dollars. The regression equation is as follows. Regression results are shown in Table 9.

$$
\begin{aligned}
& \text { DLEXRATE }(+1)=\beta_{0}+\beta_{1} D \operatorname{LINDEX}(+1)+\beta_{2} R A T E+\beta_{3} D C P I(+1) \\
& +\beta_{4} \operatorname{LNETEX}+\beta_{5} L M S+\beta_{6} D L G D P(+1),
\end{aligned}
$$

\begin{tabular}{|c|c|c|c|c|c|}
\hline $\begin{array}{l}\text { Forward } \\
\text { DLEXRATE }\end{array}$ & Factors & $\begin{array}{l}\text { Standard } \\
\text { Deviation }\end{array}$ & $\begin{array}{l}\mathrm{T} \\
\text { Value } \\
\end{array}$ & $\mathrm{P}>|\mathrm{t}|$ & $\begin{array}{ll}95 \% & \text { Confidence } \\
\text { Interval } & \\
\end{array}$ \\
\hline $\mathrm{F} 1$ & $\begin{array}{l}- \\
.0424091\end{array}$ & .0442336 & -0.96 & 0.340 & $\begin{array}{l}.1300439 \\
.0452256\end{array}$ \\
\hline INETEX & .0192058 & .0154043 & 1.25 & 0.215 & $\begin{array}{l}-.0113129 \\
.0497245\end{array}$ \\
\hline RATE & .0124141 & .0028348 & 1.38 & 0.204 & $\begin{array}{l}.0067978 \\
.0180304\end{array}$ \\
\hline LMS & $\begin{array}{l}- \\
.0850927\end{array}$ & .0658276 & -1.29 & 0.199 & $\begin{array}{l}-.2155089 \\
.0453236\end{array}$ \\
\hline DLGDP & .0657544 & .0662434 & -0.99 & 0.323 & $\begin{array}{l}-.1969946 \\
.0654858\end{array}$ \\
\hline DCPI & .0004085 & .0010616 & 0.38 & 0.701 & $\begin{array}{l}-.0016947 \\
.0025117\end{array}$ \\
\hline Cons & .6642629 & .5689691 & 1.17 & 0.245 & $\begin{array}{l}-.4629674 \\
1.791493\end{array}$ \\
\hline
\end{tabular}

Table 9 Arbitrage

It can be found that all explanatory variables, except interest rate, are insignificant in the short term. This shows that although equation (1) results in significant coefficient of all explanatory variables and a high goodness of fit, a simple manipulation of equation (1), i.e., equation (2), cannot make a good prediction. Short term prediction does not generate ideal result, so arbitrage opportunities, which reply on long-term prediction, are not likely to emerge.

\subsection{Summary}

Empirical results indicate that the ruble exchange rate has a negative correlation with oil price, i.e., when oil price decreases, ruble depreciates. When oil price rebounds slightly, then ruble increases to a certain extent.

According to the results of impulse response and variance decomposition, it can be found that the energy price represented by oil, 
explains $41.1 \%$ of changes in ruble exchange rate, while interest rate is the second most important explanatory variable, with a contribution rate of 26.7\%. Net export explains $10.6 \%$ of changes in exchange rate. From a theoretical point of view, the reason for this result may be as follows. First, net export itself is part of GDP, so the two explanatory variables are somehow correlated. Second, this paper utilizes net export to replace military export data, although there is a certain association between these two. Correlation among explanatory variables causes multicollinearity, which slightly decrease degree of freedom.

This paper finds a negative relation between energy price index, represented by oil price, and the ruble exchange rate. This finding is consistent with the theoretical prediction. It is also in line with related literature.

\section{Discussion}

China and Russia are two major economies in the world. Besides, they have a similar regional political status and economic institution. Both countries are an indispensable part of the world economic development. Two countries have a pivotal position in the development of transitional economy. The currencies of two countries, ruble and renminbi, have powerful influence regionally. The main influencing area of renminbi is concentrated in East Asia, while the main influencing area of ruble is in Eastern Europe. Since China and Russia have huge amount of international trade, and these two countries heavily invest in each other, the two currencies also influence each other. In addition, both countries are in the process of making the currency an international currency.

At present, China's internationalization of RMB is based on four factors. First, China's huge trade volume, a massive number of trade surplus makes international settlement in RMB possible, and also makes global demand of RMB growing. However, it is worth noting that China's trade surplus comes mainly from selling low-value-added goods. After the financial crisis in 2008, reduction in trade and shutdown of a large number of factories along the southeast coast caused China's GDP growth rate to fall slightly. It is first of all recommended that China should shift from selling low-value-added goods to selling technology-intensive goods in order to maintain a fast economic growth rate. Second, China is recommended to establish RMB offshore clearing centers and trading centers. At the moment China is ahead of Russia in establishing offshore banking. Only a more convenient settlement method and more secure settlement rules can make a country's currency widely accepted. The third is that China has up to 3.84 trillion dollars of foreign reserves. This factor is important, as a huge amount 
of dollars, an international currency, are in the hands of China's government. The fourth is Chinese people's confidence in RMB. Chinese people's confidence in RMB was established 66 years ago ever since the birth of RMB thanks to the government's assiduous effort to stabilize the value of RMB. Almost three decades have passed since the economic reform and opening up in 1978, people's confidence in RMB continues to grow.

Based on the study of Russia, China should form an economic pattern with various economic pillars coexisting, economic structure diversification, and rich economic development. Even if a pillar industry collapsed, it would not make a country's economy stagnant or even backward. China should follow its gradual economic transition. In the process of economic transition, it should pay attention to the speed of the transition. At present, the problem with China's capital account opening and the internationalization of RMB is that it is taking place too fast. Besides, the size and the role of foreign reserves in China's capital account deserve attention. In order to maintain healthy development of the huge Chinese economy, sufficient foreign reserves are necessary. However, there is a huge opportunity cost and lower rate of return for the huge foreign reserves. Thus, China's currency authorities must re-measure the size and role of foreign reserves for China's economic development and financial stability.

\section{Conclusion}

The devaluation of the ruble has a significant negative impact on Russia's economy. From the government point of view, devaluation of the ruble made the actual income of Russian people shrink, Russia's economic competitiveness decrease, and the actual budget of the army reduce. These weakens the government's control of the economy. The Russian government was forced to take actions to stabilize the ruble exchange rate. This largescale exchange rate hike and dollar selling strategy also brings serious sequence. The Russian government involuntarily fell into a bad cycle in which the harder it tries to control the economy, the worse the economy gets.

For businesses, companies have to raise prices constantly to cope with the depreciation of the ruble and the rising cost of imports. Such high price makes competitiveness of their products decline. Sales are suppressed, and the market share was re-divided. Companies have to raise prices to maintain original profit margins, but the net profit is still down. Some companies even shut down.

For Russia's financial institutions, on the one hand, the overall recession lead companies to watch out the cash flow. Financial institutions reduced lending to protect companies from bankruptcy. On the other hand, companies chose to settle transactions in foreign currency and hold a large 
amount of US dollars to maintain earnings. So financial institutions not only faced with the reduction of interests, but also faced with foreign exchange market risk brought by a large amount of foreign exchange losses. But financial institutions simply suspend foreign exchange business, it will make financial institution's credibility decline. For banks and other financial institutions, the credibility is the cornerstone of sustained profit. It is more important than the short-term gains and losses.

For Russia people, it costs more to buy goods, due to depreciation and higher importing costs. The rising price level seriously affected the quality of life of Russian people. In the uncertainty of the ruble value, people exchange rubles into dollars. This virtually increases the pressure of the devaluation of the ruble. People's happiness declines, which leads to further pessimism about the future economy.

The depreciation of the ruble caused large-scale evaporation of Russia's GDP, decline in corporate competitiveness, and financial instability. While short-term remedy policies were implemented to control the situation, the inevitable economic losses and economic recession had already take place. It takes a long time to reverse the situation and restores the economy.

From China's point of view, China and Russia are close trading partners, especially in the post-financial crisis era. The two countries have significantly increased the degree of interdependence. Therefore, China cannot ignore the devaluation of the ruble. The Chinese government should pay close attention to and properly deal with the ruble exchange rate. It should prevent any sudden changes in the external environment of its economy and maintain a healthy environment. China's companies should also be prepared to respond to hazard caused by the devaluation of the ruble.

\section{References:}

1. Cao. Y., The Ruble Devaluation Caused the Russian People to Worry, China Industry \& Commence News, 2014-02-11, pp. 1

2. Cheng. Y. J., Impacts and Inspirations of the Ruble Crisis, Academic Journal of Russia Studies, 2015(02), pp. 39-35

3. Chen. Y., Oil Price Nosedive Hurts Whom? China Financials, 2014(12), pp. 88-89.

4. Krugman, P., Obstfeld, M., and Melitz, M., International Finance: Theory and Policy Paul Krugman, $10^{\text {th }}$ Edition, Hawlow, United Kingdom, 2014

5. Li. J. M., Causes and Impact of Russian Ruble Crash and Opportunities for Cooperation between China and Russian, Comparative Economic \& Social Systems, 2015(01), pp. 46-57

6. Li. Z. H., Analysis of Ruble Internationalization Strategy and China- 
Russia Trade in Domestic Currency Settlement, Russia Studies, 2011(04), pp. 92-104

7. Sosunov, K. and Ushakov, N., Determination of the Real Exchange Rate of Ruble and Assessment of Long-Run Policy of Real Exchange Rate Targeting, Higher School of Economics, November, 2009, pp. 64

8. Wang. B. Y., Why Did the Ruble Fall? Eastern Europe and Central Asia Review, 1993(05), pp. 80-82

9. Xie. L. F., An Analysis of the Reasons for the Devaluation of Russian Ruble and Its Enlightenment to China, Siberia Studies, 2015(03), pp. 33-38

10. Xu. X. M., The Evolution of the Russian Exchange Rate System and the Development of the Foreign Exchange Market, International Economic Review, 2004(04), pp. 48-52

11. Xu. P. L., The Crisis and Prospect of Russia's Economy, Russia Studies, 2014(2), pp. 85-97

12. Yu. J., Research on the Impact of the Ruble Exchange Rate System over the Russian Economy. Russia Studies, 2013(06), pp. 108-122 